\title{
INSTITUUTIOISTA VERKOSTOIHIN
}

\author{
Vapaa sivistystyö kohtaa 1990-luvun muutoksen
}

\begin{abstract}
Vapaa sivistystyö on tukeutunut kahteen kivijalkaan: persoonallisuuden tasapainoiseen kehittämiseen ja demokratian vahvistamiseen yhteiskunnallisen kasvatuksen avulla. Työmuodoissa korostuu kokemuspedagogiikka. Opintokerho on oppijalähtöisen oppimisen perikuva.

Nämä tehtävät ja menetelmät pysyvät jatkossakin työn ytimenä, mutta ne saavat uuden perustelun osana muutoksen yhteiskunnan vaatimaa laajaa ammattipätevyyttä.
\end{abstract}

\section{Koulutuksesta oppimiseen}

On todennäköisesti oikein ajatella, että elämme kasvatusta, pedagogiikkaa ja didaktiikkaa koskevan ajattelun paradigmaattista murrosta. Sen taustana on yhteiskunnan kiihtyvä muutos; jatkuvasta muutoksesta on tullut pysyvä. Siirrymme teollisesta ajasta jälkiteolliseen, postmoderniin tietoyhteiskuntaan. Perinteiset sosiaaliset rakenteet heikkenevät; joukkotiedotuksen ja tietotekniikan tukemana yksilön autonomia kasvaa. Työ ja elämä muutoksen yhteiskunnassa vaatii uusia taitoja, valmiuksia ja pätevyyksiä.

Muuttuvan yhteiskunnan tärkein kompetenssi on kyky oppia muutoksen mukana uutta. Opetushallinnon alalla painopiste siirtyy koulutuksesta oppimiseen, opettamisesta itsenäisiin opintoihin, opituista tiedoista ja taidoista valmiuksiin ja laitoksista työpaikoille. Opettajan uusi ammattitaito on 'koulutuksen' sijasta kyky herättää oppimista, tukea ja ohjata oppimisprosessia sekä rakentaa hyvä oppimisympäristö.

Muutos painottaa aikuisopintojen asemaa ja perustelee elinikäisen oppimisen ajatusta. Pohjolassa tätä korostaa vanheneva väestö, jonka työkuntoisuus on inhimillisesti ja taloudellisesti tarpeellista. Aikuisten kompetenssin jatkuvasti käynnissä oleva parantaminen on Pohjolan tärkein tulevaisuuteen suuntautuva investointi. Tähän tarvitaan työ- ja yhteiskuntaelämään kietoutuva uusi oppimisen tukijärjestelmä.

Käsitykseni on, että myös opetushallinnon lakeja uudistettaessa on huolellisesti arvioitava aikuisopintojen asema. McLuhania muunnellen voi sanoa, että rakenne on viesti. Nummisen toimikunnan esityksessä aikuisopintojen viesti ei välity niiden todellisen painon mukaisella tavalla.

\section{Yhteiskunnan muutos}

Aikuisopintojen kannalta tärkeät kompetenssit juurtuvat työ- ja yhteiskuntaelämän uusiin tarpeisiin. Futurologian virittämänä yhteiskunnan muutoksesta on käynnissä vilkas keskustelu. Sen keskeisiä tuloksia voi tiivistää seuraavasti:

Globaalit markkinat. Paikallisilla ja alueellisilla markkinoilla on aina oma merkityksensä. Ihmiskunnan enemmistö elää vielä pitkään yksinkertaisen perustekniikan ja lähimarkkinoiden varassa. Silti 1900-luvun lopun oleellisin piirre on globaalien markkinoiden synty. Pääoma, tavarat, ajatukset ja osin ihmisetkin kulkevat yli vanhojen kulttuuristen, valtiollisten ja sivilisaatiorajojen uusien liikenne- ja tietoliikennevälineiden avulla. Menestyminen vaatii kilpailukykyä avoimilla markkinoilla. 
Menestyvät yritykset reagoivat nopeasti markkinoihin; ihmisten tarpeet, maut ja tyylit muuttuvat alinomaa. Työssä on kohdattava joustavasti erilaisia ihmisiä, kulttuureja, kieliä ja arvoja. Tämä koskee yhtä hyvin tavaratuotannon, palvelutuotannon, kulttuuriteollisuuden, muun kulttuurielämän kuin hallinnonkin työpaikkoja. Teknisen huippuosaamisen lisäksi menestyminen markkinoilla vaatii esteettistä, esimerkiksi muotoilun korkeata tasoa ja kulttuuriset tarpeet tunnistavaa myyntitaitoa.

Uusi tekniikka. Materiaali- ja biotekniikan ohella tietotekniikalla on ehkä vallankumouksellisin yhteiskuntaa muuttava vaikutus. ATK:n ohjaamana toisteinen, numeerisesti ohjattava rutiinityö voidaan automatisoida. Ihmisen tehtäväksi jää luova ja/tai palvelutyö. ATK:n avulla voidaan hallita suuria tuotannon ja yhteiskunnan järjestelmiä silloinkin, kun niissä toteutuu jatkuvia muutoksia. ATK yhdessä tele- ja mediatekniikan kanssa luo edellytykset verkottuvalle yhteiskunnalle, joka muun muassa nostaa tuottavuutta, vähentää etäisyyksien merkitystä ja vapauttaa luovat voimat kommunikaatioon.

Tehokkaat työorganisaatiot. Kilpailu markkinoilla edellyttää joustavia, luovuutta kannustavia ja asiakkaiden tarpeet herkästi tunnistavia työmenetelmiä ja organisaatioita. Kaikkialla, mutta erityisesti Pohjolassa tehoa haetaan ennen muuta kolmesta suunnasta. Jäykät, hierarkkiset organisaatiot korvataan erilaista ammattitaitoa kokoavilla työryhmillä, jossa ryhmä kantaa vastuun toiminnasta. Työtä ohjaavat ryhmän yhdessä johdon kanssa sopimat tavoitteet, mikä samalla palauttaa 'taylorismin' jälkeen työn mielekkyyden ja tavoitteiden toteutumisesta syntyvän työn ilon. Oppimista ja pätevyyden kohottamista kannustetaan. Työryhmä saa opintokerhon luonteen; työnjohtajasta tulee opintojohtaja.

Kestävä kehitys. Niin monimuotoinen, joustava, hallitsematon ja suunnittelematon kuin kehitys postmodernissa yhteiskunnassa onkin, sillä on yksi suuri haaste, sopeutuminen kestävän kehityksen vaatimuksiin. Pahenevat ekologiset ja terveysongelmat virittävät osaltaan myös kuluttajien eettistä tietoisuutta. Sen yksi seuraus on, että tuottajan on varauduttava selvittämään kuluttajalle tuotteensa koko elinkaaren ekologinen ja eettinen laatu. Etiikka ja ekologia ovat jo nyt keskeinen osaamisalue ja markkinavaltti. Puutteet kostautuvat vaikeasti korjattavina maineen menetyksinä.

Yhteiskunnan kolmijako. Kuvatun kehityksen tuloksena yhteiskunta näyttää olevan jakautumassa kolmeen osaan, joita työn 'pyhän' protestanttisen luonteen vuoksi on osuvasti nimitetty temppelinherroiksi, temppelinpalvelijoiksi ja uloslyödyiksi.

'Temppelinherrat' kykenevät analysoimaan symbolista tietoa. He pystyvät näkemään systeemien ongelmakohdat ja pystyvät esittämään niihin ratkaisut. Systeemianalyytikot voivat käyttää uutta tekniikkaa ja globaaleja tietoverkkoja. He ovat yhteiskunnan ja tuotannon toimivuudelle niin tärkeitä, että heille kannattaa maksaa korkeaa palkkaa. Heistä koostuvat työryhmät valtaavat tuotannon sitä mukaa, kun toisteinen työ automatisoidaan tai siirretään matalapalkkamaihin.

'Temppelinpalvelijat' tuottavat mitä moninaisimpia palveluita. He tekevät myös ne rutiini-työt, joita ei ole voitu tai haluttu automatisoida. Periaatteessa palveluita tarvitaan paljon. Myös palvelutuotannon vaatimustaso kohoaa. Tarvitaan yksilöllinen korkea laatu, esimerkiksi kulttuurinen, eettinen tai ekologinen sisältö tai sosiaalista turvaa tuova huolenpito.

Kolmas ryhmä koostuu 'uloslyödyistä', syrjäytyvistä ihmisistä. Heidän määränsä kasvaa teollisuusmaissa työn automatisoinnin, tekniikan, myös biotekniikan kehityksen takia ja siksi, että osa toisteisesta työstä siirtyy matalapalkkamaihin. Syrjäytyvät ovat uuden yhteiskunnan häviäjiä.

Nouseva kysymys on, miten syrjäytymisuhan alaisten ihmisten henkisiä voimavaroja voi vahvistaa niin, että he voivat palata temppelin sisälle. Saattaa olla, että tulevaisuudessa on mietittävä sitäkin, miten työn temppelin esipihalla voi viettää ihmisarvoisen ja arvokkaan elämän, esimerkiksi vaihtoehtoisissa elämäntavoissa. 


\section{Henkiset voimavarat}

Kuvatut yhteiskunnan muutokset havainnollistavat, miten ratkaisevassa asemassa henkiset voimavarat ja niitä kehittävä kasvatuksen ja aikuiskasvatuksen järjestelmä postmodernissa yhteiskunnassa on. Kasvatuksen kannalta oleellinen kysymys on, minkälainen ihminen voi elää täyttä ja rikasta elämää yhteiskunnassa, joka meillä jo on? Mitä valmiuksia, ominaisuuksia, kvalifikaatioita ja kompetensseja opintojen tulee kehittää?

Kysymykseen on vastattu hengästyttävän pitkillä laajojen tai totaalisten kompetenssien luetteloilla. Valmiudet ja kompetenssit voidaan aikuisopintojen tarpeita varten karkeasti ryhmitellä viiteen osaan:

(1) Ammattitekniikka. Tavallisin vastaus on hyvä ammatillinen ja tekninen koulutus. Ammatillinen osaaminen on kaiken perusta, mutta samalla työn nopean muuttumisen vuoksi ongelmallinen. Työtehtävät muuttuvat niin nopeasti, että ammattitaito on yhä useammin opittava ja sen on uusiuduttava työpaikoilla osana työn kuvaa. Oppilaitosten tehtävä on varustaa ihminen riittävin oppimisvalmiuksin.

(2) Oppimaan oppinen. Tärkein valmius on kyky oppia jatkuvasti, koko elämän ajan. Tähän kuuluu myös valmius ottaa vastuu omasta oppimisestaan ja oman oppimisensa ohjaamisesta työryhmänsä jäsenenä. Oppimaan oppimisen ydin on ajattelemaan oppiminen. Oppivan ja oppimisestaan vastuun kantavan ihmisen kehittäminen mullistaa koko totutun pedagogiikan ja didaktiikan oppijalähtöiseksi.

(3) Oman tilanteen arviointi. Vastuu omasta oppimisesta edellyttää kykyä arvioida oma tilanteensa, mikä puolestaan edellyttää kykyä ymmärtää yhteiskunnan muutosta ja siihen vaikuttavia tekijöitä, kykyä sopeutua muutokseen sekä kykyä aktiivisesti vaikuttaa muutokseen työympäristössä ja laajemminkin. Yhteiskunnallisilla opinnoilla on muutoksen maailmassa uusi merkitys muutoksen luoman ahdistumisen ja eksymisen tunteen vastapainona.

(4) Toiminta ryhmän itsenäisenä jäsenenä. Mitä enemmän ryhmät ja verkostot ottavat vastuun työstä, sitä saumattomampaa ryhmässä toimimisen kykyä ja ihmissuhdetaitoja tarvitaan. Tarvittaviin taitoihin kuuluu myös itsensä ilmaiseminen, yhä useammin myös eri kielillä ja eri kulttuurien vivahtein. Tämä edellyttää joustavuutta ja kykyä sietää erilaisuutta.

(5) Kulttuuriominaisuudet. Työssä tarvitaan yhä useammin myös esteettisiä, eettisiä ja ekologisia tietoja, jotka samalla luovat pohjan paitsi ihmisen sisäiselle tasapainolle myös luovuudelle ja monipuolisuudelle. Vanhastaan näitä on nimitetty ihmisen kulttuuriominaisuuksiksi. Esimerkiksi hyvä esteettinen maun ja tyylin osaaminen on tärkeä osa myyntikelpoisten tuotteiden kehittelyä. Monissa palveluissa on niihin sisältyvä esteettinen komponentti osa kokonaiselämystä.

Luettelo ei ole uusi keksintö. Esimerkiksi ruotsalainen aluetieteilijä Åke E. Andersson on pitänyt alueiden kehityksen kannalta ratkaisevana niiden kykyä kehittää ns. k-ominaisuuksia; ruotsissa sanat tieto, taide, luovuus ja viestintä alkavat k-kirjaimella. Näiden merkitys kuitenkin entisestään kasvaa.

Nyky-yhteiskunnan tarvitsemien kompetenssien analyysillä on pitkällemeneviä vaikutuksia kaikkeen opetushallinnon alaiseen toimintaan. Ns. koulutus on viritetty teollisen yhteiskunnan mallin mukaan tuottamaan opettajan ohjaamilla oppitunneilla tasalaatuisia ammattilaisia pysyvän tai hitaasti muuttuviin työtehtävän. Nyt koko pedagogiikka on muutettava valmiin tiedon/taidon kouluttamisesta jatkuvan oppimisen valmiuksien rakentamiseen. Tärkeämpiä kuin faktuaaliset tiedot ja taidot ovat prosessuaaliset valmiudet ja pätevyydet. 
Luettelo nostaa henkisten voimavarojen kehittämisen ja sitä tukevat aikuisopinnot yhteiskuntien strategiseksi investoinniksi. Tähän ei riitä yksin tutkintotavoitteinen aikuisoppiminen, vaikka sekin on tärkeää. Yhtä vähän tarvitaan kiihtyvää, todellisuudesta irrallaan olevaa kurssimyllyä. Perimmäinen haaste on luoda sellainen oppimista tukeva järjestelmä, joka asettuu aitoon vuorovaikutukseen työ- ja yhteiskuntaelämän tarpeiden kanssa.

\section{Vapaa sivistystyö}

Muutoksen yhteiskunnassa tarvittavien kompetenssien analyysi on herättänyt uuden itseluottamuksen pohjoismaisessa vapaassa sivistystyössä. Esimerkiksi 'Kultalaatat ruohikossa' -raportin työstänyt pohjoismainen aikuiskasvatusta pohtinut aivoriihi sanoo, että ns. laaja kompetenssi on hämmästyttävästi samanlainen kuin grundtvigilaisen vapaan sivistystyön perinteinen ja pohjoismaisiin yhteiskuntiin syvälle vaikuttanut tehtävä. Tämä voi joskus olla vaikea nähdä Suomessa, jossa vapaan sivistystyön traditio on ohuempi kuin muissa pohjoismaissa.

Vapaan sivistystyön taustana olevaan humanistiseen ihmiskäsitykseen on kuulunut itsearvoisena ihanne, jonka mukaan ihmisen tulee kehittää tasapainoisesti kaikkia itsessään olevia mahdollisuuksia.

Vapaa sivistystyö on tukenut perustelunsa kahteen kivijalkaan: persoonallisuuden tasapainoiseen kehittämiseen ja demokratian vahvistamiseen yhteiskunnallisen kasvatuksen avulla. Työmuodoissa korostuu kokemuspedagogiikka. Opintokerho on oppijalähtöisen oppimisen perikuva. Nämä tehtävät ja menetelmät pysyvät jatkossakin työn ytimenä, mutta ne saavat uuden perustelun osana muutoksen yhteiskunnan vaatimaa laajaa ammattipätevyyttä.

Yliopistojen täydennyskoulutus ja osin ammatillinen aikuiskoulutus on viime vuosina laajentunut kehittämään myös 'laajaa' kompetenssia. Kehityksen voi odottaa jatkuvan. Silti osasta laajoja kompetensseja on kasvamassa arvopohjaiselle vapaalle sivistystyölle juuri sille ominainen tehtäväkenttä. Se voi tarjota laajoja kompetensseja kehittäviä oppimisympäristöjä ja tuottaa siihen tarvittavaa tietoa ja osaamista. Vapaalle sivistystyölle jää tämän ohella omia, vain sille ominaisia tehtäviä osana aikuiskasvatusta.

Tästä kokonaisuudesta nousee vapaan sivistystyön 90-luvun työnäky ja samalla lain vapaasta sivistystyöstä perustelu. Vapaa sivistystyö koskee ennen muuta yksityistä ja arvopohjaista toimintaa kansanopistoissa ja opintokeskuksissa. Niiden toiminta tulee oppia näkemään verkottuvana kokonaisuutena, jossa toimii instituuttimuotoisia ja hajautettuja osia. Kansalaisopistojen toiminta tässä kokonaisuudessa on arvioitava erikseen.

\section{Sivistystehtävät}

Vapaan sivistystyön luovuttamaton ominaisuus on vapaus, joka sisältää vapauden hakea itse tehtävänsä, työmuotonsa, pedagogiikkansa jne. Vapaus saattaa johtaa myös vapauden väärinkäyttöön. Vapauden rakenteet saattavat täyttyä sisällöllä, jonka perustelu osana vapaata sivistystyötä ei kestä. Siksi tarvitaan elävää keskustelua vapaan sivistystyön aidosta tai omimmasta tehtävästä. Tätä edellyttävät myös tulevaisuuden tulossopimuspohjaiset rahoitusmallit. Seuraava esitys ei kata vapaan sivistystyön koko aluetta, mutta nostaa esiin kolme 1990-luvun lopun tilanteessa keskeistä työalaa.

Kulttuuridiversiteetti. Vapaan sivistystyön taustana olevaan humanistiseen ihmiskäsitykseen on kuulunut itseisarvoisena ihanne, jonka mukaan ihmisen tulee kehittää tasapainoisesti kaikkia itsessään olevia mahdollisuuksia. Tätä koskevan omaehtoisen harrastamisen alaan kuuluu tiedollisen ja eettisen pohdinnan lisäksi moninainen esteettinen toiminta. Vapaan sivistystyön suomalainen arki on paljolti sitä, että tälle luodaan suotuisat puitteet. 
On esimerkiksi edelleenkin vaikea löytää tehokkaampaa tapaa kehittää laajaa kompetenssia kuin perinteinen seuranäyttämötoiminta. Se opettaa samaan aikaan projektityötä, kulttuurin ymmärtämistä, eläytymiskykyä ja joustavuutta, ryhmätyötä ja ihmissuhdetaitoja, esiintymis- ja ilmaisutaitoa, sosiaalista rohkeutta jne.

Sivistystyön etu on - Liisa Korhosen osuvan sanonnan mukaan - sen kyky luoda yhteyksiä, tilanteita joissa samasta teemasta kiinnostuneet voivat kohdata ja joissa jokin teema voidaan luodata läpikotaisin esimerkiksi tiedollisista ja taiteellisista lähtökohdista. Käytännössä näin syntyvillä yhteyksillä ja herätteillä saattaa olla suuri merkitys.

\section{Suomi poikkeaa muista teollisista maista arkuudessa, jolla se suhtautuu arvopohjaiseen toimintaan. Suuri osa vapaasta sivistystyöstä on Suomessa organisoitu osaksi julkishallintoa puolueettomiksi kansalais- ja työväenopistoiksi.}

Monimuotoinen tiedollinen, eettis-elämänkatsomuksellinen ja esteettinen harrastus on sitä yhteiskunnan kulttuurista diversiteettiä, joka on luovuudelle ja kehitykselle ainakin yhtä tärkeää kuin biodiversiteetti on luonnolle. Luovuus on useimmiten juuri kykyä yhdistää yllättäviä asioita keskenään joksikin uudeksi.

Persoonallisuutta ja ihmisen kulttuuriominaisuuksia kehittävää harrastamista on perusteltu sillä, että se toimii vapaa-ajan rikastajana ja usein yksitoikkoisen työn vastapainona. Tämä pitää edelleen paikkansa. Käsitys työn vaatimista laajoista kompetensseista antaa toimintaan uuden näkökulman. Harrastaminen kehittää samalla työssä tarvittavia henkisiä voimavaroja. juuri tästä syystä moni moderni yritys kannustaa henkilöstönsä harrasteita.

Yhteiskunnallinen kasvatus. Nopean muutoksen yhteiskunnassa yhteiskunnallisen kasvatuksen tehtävät ja merkitys on arvioitava uudestaan. Saatavaa tietoa tarvitaan oman aseman arvioimisessa, mutta myös muutosten kansanvaltaisessa hallinnassa. Opintotoiminta on yksi yhteiskuntaan osallistumisen tapa. Perustyön lisäksi vapaa sivistystyö voi arvopohjaisesti toteuttaa suuriin muutoksiin tai uudistushankkeisiin liittyviä kampanjoita. Ajankohtainen esimerkki on EU-tietous.

Vapaa sivistystyö on Suomessa valtion ainoa panostus arvopohjaiseen tutkimukseen ja kasvatukseen. Panostus on Suomessa oleellisesti pienempi kuin muissa pohjoismaissa. Se on myös pienempi kuin anglosaksisissa maissa ja esimerkiksi Saksassa, joissa vastaavat toiminnot ovat arvopohjaisten säätiöiden tai think tank'ien tehtävänä.

Suomi poikkeaa muista teollisista maista myös arkuudessa, jolla se suhtautuu arvopohjaiseen toimintaan. Suuri osa vapaasta sivistystyöstä on Suomessa organisoitu osaksi julkishallintoa, puolueettomiksi kansalaisja työväenopistoiksi. Taustana saattaa olla harmonisuutta arvostavan kansanluonteen lisäksi esimerkiksi kansalaissodassa syntyneet kokemukset ja Bysantin varjossa hoidettavaan politiikkaan usein liittyvä kohtalonomaisuus.

Pohjoismainen perinne painottaa kansalaisten keskustelun ohella enemmän koulumaista valmiin tiedon jakamista kuin esimerkiksi anglosaksinen, jossa yhteiskunnallista tietoa tuottavalla policy studies -tyyppisellä tutkimuksella on keskeisempi asema.

Vapaa sivistystyö syntyi aikana, jossa yhteiskunnan kehitys oli hidasta, muutosta voitiin ymmärtää suurten ideologioiden avulla ja jossa tieteellinen tieto oli nykyistä yksiselitteisempää. Vapaa sivistystyö oli 'annetun' tiedon jakokanava ja synnytti sen ohella päättäjien ja kansalaisten vuorovaikutuksen. Olof Palme sanoikin Ruotsia opintokerhodemokratiaksi. 
Yhteiskunnallinen oppiminen tarvitsee uutta ajattelua, jossa tapahtuneet muutokset otetaan huomioon. Ensinnäkin toimintaa tulee oleellisesti lisätä. Demokratian toimivuus on lähivuosina haasteellisella koetuksella kaikissa teollisissa maissa. Demokratiaa voidaan kuitenkin tietoisesti vahvistaa tarttumalla aikuisoppimisen keinoin rohkeasti sen haasteisiin. Lähtökohtina voisivat olla esimerkiksi seuraavat:

(1) Mitä nopeampaa yhteiskunnan muutos on, sitä enemmän siinä tarvitaan muutosta tutkivaa ja tulkitsevaa yhteiskunnallista aikuisoppimista. Opintojen tehtävänä on auttaa muutokseen sopeutumisessa, löytää keinoja aktiivisesti vaikuttaa muutokseen ja oppia arvioimaan oma asemansa suhteessa muutokseen. (2) Yhteiskuntaa koskeva aikuisoppiminen tulee organisoida arvoperustaisesti. Sen ei tarvitse merkitä luopumista harmonian ihanteesta. Yhteiskunnan kokonaisuudelle on sitä parempi, mitä syvemmin eri ihmisryhmät, aatteet, edut ja intressit voivat omista lähtökohdistaan tulkita tapahtuvaa ja tarjota aineksia keskusteluun. Tuloksena on muutoksen yhteiskunnassa syntyvien ongelmien ja korjausehdotusten läpivalaisu ilman katvealueita. (3) Nopean muutoksen ja tietoräjähdyksen maailmassa on tärkeää, että kasvatustyötä tekevät instituutiot voivat organisoida myös omaa tiedon tuottamista. Snellmanilainen tutkimuksen ja opetuksen yhteys pätee sitä enemmän, mitä vaativammaksi oppiminen tulee. Tarvitaan tutkimuksia, selvityksiä, policy-dokumentteja, aivoriihiä jne.

Syrjäytymisuhan alaiset. Pohjoismainen vapaa sivistystyö on vanhastaan panostanut ihmisiin, joilla on puutteellinen perussivistys. Suomessa tämän osuus on ollut vapaan sivistystyön voimavarojen pienuuden vuoksi muuta Pohjolaa heiveröisempi. Työttömyyden ja syrjäytymisen (mutta myös siirtolaisuuden) kasvu tuovat kuitenkin uusia haasteita vapaan sivistystyön tasa-arvoperinteelle.

Pohjolan kansojen hyvä yleissivistys, oppimisen arvostus ja maailman avoimet markkinat ovat hyvä lähtökohta menestymiselle muutoksen maailmassa. Menestyvimmät yrityksemme pystyvät uusimpaan tekniikkaan ja globaaleihin strategioihin. On myös viitattu siihen, että Suomessa olisi tilaa kymmenille tuhansille pienille yrityksille joko osana syntyviä alihankinnan verkostoja tai henkilökohtaisessa palvelutuotannossa ja käsityöläisyydessä. Suomella on hyvät lähtökohdat menestyä aikuisten jatkuvalle oppimiselle rakentuvassa maailmassa.

Silti perinteisten ammattien nopea katoaminen yhdessä automaation ja matalapalkkamaiden kilpailun kanssa kasvattavat nopeasti syrjäytymisuhan alaisten ihmisten määrää. Tämä koskee maaseutua, mutta yhtä hyvin monia taajamien ja kaupunkien ammatteja. Rohkeimmatkin poliittiset tavoitteet merkitsevät sitä, että Suomi varautuu ainakin parin sadan tuhannen ihmisen työttömyyteen. Syrjäytyminen on myös EU:ssa tiedostettu kipeäksi ongelmaksi.

Työttömyyden ja syrjäytymisen ehkä pahin seuraus on sen vaikutus ihmisen itsetuntoon ja -luottamukseen. Seurauksena on kierre, jossa pelkoa ja epävarmuutta seuraa käpertyminen, henkiset ongelmat, apatia ja luovuttaminen.

Oma vapaan sivistystyön laki osoittaisi, että Suomi on edelleen - vaikkakin vähemmin voimavaroin - pohjoismaa ja rakentaa opetushallintonsa pohjoismaisen sivistyskäsityksen varaan.

Ennen uuden henkisen pohjan rakentamista suuretkin panostukset ammatilliseen koulutukseen saattavat johtaa vain turhauttavaan kurssimyllyyn. Uutta pohjaa rakentava toiminta on jätetty yksinomaan terapian tehtäväksi, vaikka siinä ennen muuta tarvitaan vapaan sivistystyön perinteen mukaisia aikuisopintoja. Osin ne voidaan yhdistää muuhun toimintaan, esimerkiksi tietotekniikan opiskeluun.

Vapaa sivistystyö on jo nyt käytössään olevin pienin voimavaroin osoittanut, että se kykenee vahvistamaan syrjäytymisuhan alaisten ihmisten henkisiä voimavaroja. Tähän reseptiin kuuluu toiminta, jossa pyritään ymmärtämään aikamme muutosta, arvioimaan omaa tilannetta ja mahdollisuuksia, tutkimaan omia voimava- 
roja ja vahvistamaan itsetuntoa, pohtimaan henkisen hyvinvoinnin tekijöitä, kehittämään 'laajoja' kompetensseja ja tällä tavoin vahvistamaan ihmistä uuteen ammattiin ja sen mukaiseen koulutukseen.

Syrjäytymisuhan alaisten ihmisten vahvistaminen uuteen alkuun on tärkein tehtävä. Saattaa silti olla, että jatkossa tulee pohdittavaksi myös vaihtoehtoinen tavoite. Voi olla, että kaikille ihmisille ei missään oloissa lähivuosina ole palkkatyötä tai reaalista mahdollisuutta yrittämiseen tai muuhun omatoimiseen tulonhankintaan. Myös näiden ihmisten tulee voida elää elämänsä ihmisarvon mukaisella tavalla. jos näin on, vapaa sivistystyö on sopiva organisaatiopohja kehittämään työn ulkopuolisia vaihtoehtoisia, mutta silti rikkaita ja henkisesti täyteläisiä elämisen tapoja. Kultataulut ruohikossa -raportin suosittama elämänkompetenssi on tietysti tarpeen myös muille kuin syrjäytyville.

\section{Laki vapaasta sivistystyöstä}

Luetellut vapaan sivistystyön tehtävät ovat vain osa kokonaisuudesta. Ne kuitenkin osoittavat, että vapaalla sivistystyöllä on ajankohtaisia, yhteiskunnalle tärkeitä tehtäviä. Myös säästävän yhteiskunnan kannattaa sijoittaa opetushallinnon varoista vapaaseen sivistystyöhön osa opetushallinnolle osoitettavista varoista. Tämän lisäksi jatkossa voi odottaa ad hoc-luonteisia hankkeita ja kampanjoita, joiden tarkoitus on valmentaa kansalaisia yhteiskunnan muutoksiin.

Parhaiten tämä toteutuu oman vapaan sivistystyön lakinsa turvin. Oma laki osoittaa ensinnäkin, että Suomi on edelleen - vaikkakin vähemmin voimavaroin - pohjoismaa ja rakentaa opetushallintonsa pohjoismaisen sivistyskäsityksen varaan. Toiseksi oma laki tekee vapaan sivistystyön taloudellisesti mahdolliseksi, vaikka se ei anna tutkintotavoitteista opetusta eikä sillä ole muita julkisia maksajia. Vapaa sivistystyö voi kehittää samalla laajoja kompetensseja koskevaa osaamista ja asiantuntemusta siten, että sen vaikutus voi heijastua laajemminkin.

Vapaa sivistystyö ei juurikaan anna tutkintotavoitteista opetusta. Asiantilaa tuskin kannattaa jatkossakaan muuttaa. Tutkinnon sijasta tulossopimus sopii vapaaseen sivistystyöhön hyvin. Sen periaatteita voitaisiin ennakkoluulottomasti kokeilla tällä alueella.

Tulossopimukset tekevät vapaan sivistystyön sisällön ja tavoiteltavat tulokset julkisiksi ja samalla 'läpinäkyviksi'. Tulossopimukset auttavat arvioimaan, miten paljon yhteiskunnan varoja vapaaseen sivistystyöhön on järkevää käyttää. Tärkeä seuraus on se, että tulossopimus 'pakottaa' vapaan sivistystyön organisaatiot perustelemaan, millä erityisellä tavalla heidän työnsä on vapaata sivistystyötä. Pelisäännöissä on turvattava se, ettei viranomainen tai poliittinen valta voi antaa vapaan sivistystyön tehtäviä. Arvopohjaisen toiminnan on jatkossakin voitava vapaasti hakea tehtävänsä ja päättää sen toteuttamisen tavoista. 